\title{
Carnation Atoms? A History of Nuclear Energy in Portugal
}

\author{
Tiago Santos Pereira ${ }^{1}$ \\ Paulo F. C. Fonseca ${ }^{2}$ \\ António Carvalho ${ }^{1}$
}

\begin{abstract}
Drawing upon the concepts of civic epistemologies and sociotechnical imaginaries, this article delves into the history of nuclear energy in Portugal, analyzing the ways in which the nuclear endeavor was differently enacted by various sociopolitical collectives - the Fascist State, post-revolutionary governments and the public. Following the 1974 revolution - known as the Carnation Revolution - this paper analyzes how the nuclear project was fiercely contested by a vibrant antinuclear movement assembled against the construction of the Ferrel Nuclear Plant, the first sociotechnical controversy in Portugal, paving the way for the emergence of a combative civic epistemology. Supported by semi-structured interviews with scientists, activists and local residents of Ferrel and the analysis of historical material, this article presents the failed Portuguese nuclear endeavor as an emblematic case study to explore the co-production of science and society, in particular the role of revolutionary processes in the unfolding of sociotechnical controversies.
\end{abstract}

Keywords: Nuclear energy; Civic epistemologies; Sociotechnical imaginaries; Energy policy; History of science and technology

\footnotetext{
${ }^{1}$ Centre for Social Studies, University of Coimbra, Coimbra, Portugal

${ }^{2}$ Federal University of Recôncavo da Bahia, Cruz das Almas, Brazil
}

Tiago Santos Pereira (tsp@ces.uc.pt)

Paulo F. C. Fonseca (dopaulo@gmail.com)

António Carvalho (antoniomanuelcarvalho@gmail.com) 


\section{Introduction $^{1}$}

Although there are no nuclear power plants in Portugal, nuclear energy has been present in its history, and until recently it evoked heated debates. Since the beginning of the 20th century, Portugal exported uranium and developed human and physical infrastructures to support the nuclear endeavor, imagined as a driver of modernization.

The failed Portuguese nuclear project is an emblematic case to analyze how sociotechnical options are differently enacted by social collectives and political regimes, triggering conflicting sociotechnical imaginaries. Since the evolution of the Portuguese nuclear project intersected with the 1974 Revolution, leading to massive anti-nuclear demonstrations from 1976 onwards, it is a good example to contrast Fascism and Democracy, and how these regimes perform distinct science/society couplings.

In this article we flesh out a history of nuclear energy in Portugal as illustrating a tension between technoscience, development and Democracy, highlighted by the clash between a major technological project and a combative civic epistemology. The material stems from the research project Nuclear Portugal (2010-2013), focused on the history of nuclear energy in Portugal and its associated controversies. We explored a large collection of press articles, parliamentary debates, books, technical documents, relevant legislation and interviewed scientists, activists and lay citizens.

In a previous article (Santos Pereira et al. 2016), we analyzed the history of nuclear energy debates in the Portuguese Parliament, arguing that Portuguese nuclear ontologies became increasingly risky, as the nuclear endeavor, initially dominated by economic and technocratic dimensions, was progressively characterized by social, environmental and health concerns.

However, parliamentary debates only provide a partial view of social, political and cultural dynamics. Although they reflect broader social phenomena, in order to tackle the complexity of technological options the actions and discourses of a wide range of actors must be taken into account, as sociotechnical controversies are highly heterogeneous and are not limited to official fora of political deliberation.

Therefore, in this article we analyze how a heterogeneous assemblage composed of activists, scientists, local inhabitants and politicians performed the Portuguese nuclear controversy. We explore how the emergence of a democratic civic epistemology after the 1974 Revolution enacted a multitude of conflicting imaginaries on nuclear development, inquiring whether the demise of the nuclear option can be exclusively explained by democratization processes.

Our article is particularly indebted to the work of Jasanoff, especially the coproductionist concepts of civic epistemology (Jasanoff 2005; Miller 2008) and sociotechnical imaginaries (Jasanoff and Kim 2009; Jasanoff 2015). We resort to these concepts to analyze how the 1974 Revolution reshaped public ways of

\footnotetext{
1 The first draft of this article was presented at the 12th Annual Science and Democracy Network (SDN) Meeting at the University of Harvard in 2013. The SDN was founded by Sheila Jasanoff, whose work on civic epistemologies and sociotechnical imaginaries strongly influenced our stance on the history of nuclear energy in Portugal.
} 
knowledge making, assessing the impacts of revolutionary processes of social change on science/society couplings.

The notion of co-production means that "the ways in which we know and represent the world (both nature and society) are inseparable from the ways in which we choose to live in it" (Jasanoff 2004: 2). Jasanoff suggests that scientific knowledge "both embeds and is embedded in social practices, identities, norms, conventions, discourses, instruments and institutions" (ibid: 3). Following Jasanoff's insights, this paper offers a historical account of the co-production of major sociopolitical changes (the 1974 Revolution) and sociotechnical projects (Portuguese nuclear policies), illustrating the couplings of sociopolitical and technological orders.

Sociotechnical imaginaries can be defined as "collectively held, institutionally stabilized, and publicly performed visions of desirable futures, animated by shared understandings of forms of social life and social order attainable through, and supportive of, advances in science and technology" (Jasanoff 2015: 4). They can be seen as an illustration of how technical and social orders are co-produced. We will show how Portuguese sociotechnical imaginaries on nuclear energy were affected by a new civic epistemology, contrasting the nuclear imaginary of the Fascist State with the emerging post-revolutionary imaginaries.

Civic epistemologies are "the social and institutional practices by which political communities construct, review, validate, and deliberate politically relevant knowledge" (Miller 2008: 1896). They can be seen as patterns of public legitimation of decision-making processes; the ways in which publics assert credibility to politically relevant scientific knowledge - the shared understandings of "what credible claims should look like and how they ought to be articulated, represented and defended" - are an integral part of democratic political cultures (Jasanoff 2005: 249). Civic epistemologies are a key dimension to modern political regimes, and the transition from Fascism to Democracy allowed citizens to attain an active voice which resulted in more robust demands for accountability and public involvement in decision-making.

Civic epistemologies are also interesting to highlight the differences between Fascism and Democracy. In Fascist Pigs, Tiago Saraiva builds on the notion of technoscientific organisms to delve into the co-production of science and society in three Fascist States: Portugal, Spain and Italy. Saraiva's book explains how technoscientific entities embed and are embedded by Fascism, thus materializing political projects:

the increasing ability to tinker with plant and animal life (...) enabled the materialization of different political projects, alternative modernities, good and bad, Fascism being clearly among the bad ones. (Saraiva 2016: 12)

Saraiva's work examines many examples of how Fascism and technoscientific artifacts were co-produced, illustrating the performative capacity of science and technology and the ontological politics (Mol 1999) of certain political regimes:

Mass mobilizations, new State structures, organic communities, and imperial expansionism (...) were imagined and enacted through the breeders' new 
organisms: wheat, potatoes, pigs, sheep, coffee, rubber, and cotton. The study of the making and growing of such organisms can thus been described as a study in fascist ontology. (Saraiva 2016: 14)

Saraiva's study in Fascist ontology didn't include the history of nuclear energy. However, as we will argue, the Portuguese nuclear endeavor is a particularly emblematic exemplar to analyze the sociotechnical imaginary of the Portuguese dictatorship and the "fascist nationalistic obsession with self-reliance" (Saraiva 2016: 8). Moreover, the end of the Fascist dictatorship and subsequent public opposition to the project is a fertile ground to delve into the clash between Democratic and Fascist ontologies and their conflicting sociotechnical imaginaries.

\section{The Birth of Portuguese Nuclear Imaginaries}

In 1926, a coup d'état ended the first republican period in Portugal, leading to the implementation of a dictatorial regime, the New State. From 1933 to 1969, Dr. António de Oliveira Salazar ruled the country as Prime-Minister, following a brief period as Minister of Finance. From 1969 to 1974, his successor, Marcello Caetano, struggled to maintain the regime's hegemony until a military coup on the $25^{\text {th }}$ of April forced him to resign. Salazar's government kept Portugal under a strict nationalist and corporatist ideology, largely isolated internationally. Guided by the moral triad God, Fatherland and Family, the regime promoted rural life as the image of tradition and nationalism, restraining the effects of industrialization. The military controlled the government and scientific research was kept under close scrutiny. Universities were seen as a berth for the initial training of technocratic elites and were submitted to a pervasive control and censorship which kept research contained under the regime's ideology (Saraiva 2016).

Since 1907 Portugal was aware of significant radium-uranium reserves in its territory and mining activities were established, initially under the operation of a British company, later nationalized (Castaño 2011). By the end of World War II, Portugal was the third largest producer of uranium concentrates in the West, which were sold to the UK and the US (Oliveira 2002). Meanwhile, research on nuclear physics and on ionizing radiations was carried out through the determination of some university professors and their disciples, struggling to follow the discoveries developed in Europe (Jorge and Costa 2001).

Until the end of WWII, Portuguese nuclear imaginaries situated the country as a strategic producer and exporter of radioactive minerals, a condition strengthened after the identification of potential reserves in its African colonies, Mozambique and Angola (Ferreira 2004). Radioactive minerals would play an important role in the strategic planning that coupled continental nuclear energy with colonial mining and expectations of international trade and military alliances. 
Until the mid-1970s, nuclear energy populated the imaginary of Portuguese government bureaucrats, and was internationally promoted as a symbol of modernity (Hecht 1998). However, the early nuclear States of post-WWII, such as India, displayed a "presence of more than one meaning of nuclear practices" (Abraham 2006: 56). In Portugal, the same ambivalence was present, related to an ambiguous position of governments towards the development of nuclear technology, including both military and civilian applications (Abraham 2006). Although there was no explicit goal to develop nuclear weapons, the National Energy Board (JEN) was run by members of the military, and that aspiration was present in some elements of the Fascist elite.

Jasanoff and Kim (2009) suggest that distinct imaginaries characterize US and South Korea's relationship to nuclear power. The American one is focused on security and containment, while the Korean imaginary is grounded on ideals of national development and sovereignty. The sociotechnical imaginary of the Portuguese Fascist State was characterized by ideals of development, sovereignty and modernization, indicating an alignment with the technocratic rationality internationally fostered through the Atoms for Peace discourse (Hecht 2006), and an explicit attempt to benefit from uranium reserves.

During the post-WWII years the Portuguese government followed the international imagination of an emerging nuclear era, fueled by mixed fillings of peaceful development and techno-military prowess (Abraham 2006). In 1954, one year after Eisenhower's Atoms for Peace speech to the UN, the government created the Portuguese Nuclear Energy Board (Junta de Energia Nuclear - JEN) to coordinate all activities related to the future production of nuclear energy, and a Nuclear Energy Studies Commission (CEEN) to develop research capabilities (Rollo et al. 2012). JEN started a detailed prospection of continental and colonial uranium reserves and initiated a medium-term program of advanced training of human resources on nuclear applications (Oliveira 2002); it was highly situated in the government's hierarchy, reporting directly to Salazar's office.

When JEN was inaugurated by Salazar, the potential economic benefits of nuclear energy were highlighted, indicating a sociotechnical imaginary that envisioned nuclear power as a driver of development and sovereignty, allowing Portugal to use its uranium reserves for nuclear energy production instead of exclusively exporting them:

(...) we need to be focused on the mobilization of the potential resources that Portuguese territories, continental and ultramarine, apparently possess. It may well be that Providence, being greedy with us regarding well known energy sources - coal, oil and even hydric power - perhaps benefited us somehow with some uranium and other minerals, to be explored in the future. (Salazar 1954: 432).

As mentioned by Professor João Caraça, a former member of JEN, the Portuguese sociotechnical imaginary on nuclear energy was ambivalent. Although 
publicly nuclear was promoted as a driver of modernity, development and sovereignty, behind closed doors the possibility of military uses was also present:

We had uranium reserves in Portugal, and also in the colonies. So, those resources gave us some leverage, some capacity, in international terms, that's what they [the fascists] believed. And nuclear power was somehow captured by the military, therefore we had a very important General, Kaúlza de Arriaga, nominated as president of JEN. (...) He didn't talk openly about weapons, but there was always that issue. Even because we were under the Atoms for Peace program. The laboratory was funded by that program. (Interview, João Caraça, May 2013)

The nuclear option also represented a relevant international door for the regime it was not an isolationist goal as it fostered various forms of cooperation with other States. On the basis of its nuclear fuel reserves, providing a distinguished position in international fora (Hecht 2011), Portugal was part of the first list of signatories of the International Atomic Energy Agency (IAEA) and of the European Society of Atomic Energy (ESAE). With significant technical and financial support from the United States' Atoms for Peace policy (Hecht 2006), a Physics and Nuclear Engineering Laboratory (LFEN) was then created by JEN and a nuclear research reactor started running in 1961 (Jorge and Costa 2001). During the Cold War, Portugal benefited from its alignment with the US. The country commissioned almost $100 \%$ of the construction of the US model swimming pool reactor (Gaspar 2011) and in 1966 a cooperation agreement with the US was signed at the IAEA (IAEA 1966). A generous nuclear budget provided advanced training for future JEN brainpower in the US, France and UK, in a period when research was incipient in Portugal. As put by its first director, JEN was considered the "elite institution for Portuguese scientists" (Jorge and Costa 2001: 67).

The private sector built a consortium composed of electric utilities, industrial firms, a bank and private investors, forming the Portuguese Company of Nuclear Industries (CPIN). Anticipating future economic benefits, CPIN aimed to provide the necessary knowledge and national production capacity to the future nuclear energy sector (Galvão 2013).

JEN's mission encompassed prospection, safety and research, and in 1968 the government requested JEN to develop a study on suitable locations for a nuclear plant, expecting that its construction would start in the mid-1970s. Simultaneously, the Portuguese Company of Electricity was promoting other studies, with French support, to support the planning process (Oliveira 2002, 2005).

By the beginning of the 1970s there were substantial reports about where, when and how to build the first nuclear plant, and in 1974, a location near Ferrel, a small coastal village with 2,000 inhabitants, was chosen as the most suitable site (Cabral and Fernandes 1975). Facing significant industrial expansion following the post-war decades, the government, academia and industry reiterated that the country's engagement with nuclear energy was the best option to solve the imminent exhaustion of hydric resources. Portuguese uranium resources would be a cheap alternative to foreign oil, fostering scientific, technological and industrial development. 
The government, controlled by an elite of politicians and technocrats, pursued the nuclear project following the general technocratic approach adopted worldwide, viewing the construction of nuclear plants as a necessary move towards development and modernity (Rollo et al. 2012). The nuclear endeavor was considered the first high-tech project of the Fascist State, becoming a breeding ground for technoscientific elites - the perspective among the scientific community was that this project would greatly benefit Portuguese science and technology. According to Professor Caraça:

That's why JEN was created... there were all those training programs, nuclear engineers, nuclear safety - our goal was to foster a stronger national incorporation. What we said was... we will use the nuclear plant to create... to educate scientists, to develop the first sector of high technological density in Portugal. What would become the first high-tech sector of Portugal. (Interview, João Caraça, May 2013)

Another former member of JEN told us that there were no voices against the nuclear option. There were internal discussions about when and how the project should be undertaken, but no room for opposition - in the monolithic opinion that shaped dictatorial sociotechnical imaginaries, nuclear energy was seen as a great opportunity. From the 1950s to the 1970s, the incorporation of nuclear energy into the electrical grid was recognized as a future certainty.

In this scenario, it is unfair to talk about a civic epistemology. Portuguese citizenry had no active role in the construction of a sociotechnical imaginary on nuclear technology. The authoritarian government repressed any kind of protests or dissent (Hamann and Manuel 1999) and the censored press and television kept a positive attitude towards this technology, "marked by the enthusiasm and euphoria towards scientific progress brought by nuclear energy and its pacific (...) applications (...)" (Schmidt 2003: 232).

\section{Nuclear Plans in Turbulent Times: The Colonial War and the End of the New State}

Even if national transmissions and the official sociotechnical imaginary of the Fascist State presented nuclear energy as a driver of development and sovereignty, there were significant barriers to its implementation. By the end of the 1960s, the uranium market was not as active as before, the technological challenge to enrich national reserves was no longer trivial (Castaño 2011) and core nuclear technologies would have to be imported. The CPIN's short life (1958-1964) shows that, while nuclear energy capacity was highly regarded, there were significant barriers that kept national entrepreneurs apprehensive (Ribeiro et al. 1987).

JEN's organic structure relied on isolated organisms of action and its direction was based on insufficient strategic command (Jorge and Costa 2001), and there were recurrent reforms to improve its governance (Oliveira 2002). In 1974, JEN was submitted to the command of the recently created Ministry of Industry and Energy (Oliveira 2013). This illustrated a shift in the government's nuclear strategy, in line 
with the interests of national and international energy industries to achieve more consistent results in a short period of time (Caraça 1978). Once it became clear that the project would require direct industry investment, JEN would gradually lose its influence in the energy industry sector, leading to its extinction in 1979 (Saraiva et al. 2008).

Another decisive factor was the Colonial War. During the 1960s, Portugal's ambitions included prospecting for uranium ore in Angola and Mozambique (Ferreira 2004), in order to make sure that the country would profit from its African reserves; however, the emergence of African independence movements, leading to the Portuguese Colonial War, compromised these plans.

From 1961 to 1974, the government continually increased its military and economic efforts to control African colonies. This took a toll on the national budget, compromising the nuclear project and eroding the economic and political stability of the regime (Schmitter 1999). By the early 1970s, the conflict was draining an unsustainable amount of financial and human resources, and it was a decisive reason behind the coup d'état on April 25, 1974 (Rosas 2003).

Thousands of people on the streets giving carnations to soldiers, who did not even had to fire their weapons, is the symbol of what is known as the Carnation Revolution. Portugal was finally liberated from Fascism, and African colonies would eventually be freed from Portuguese colonization.

\section{Carnation Times: The Emergence of Public Participation}

The Carnation Revolution fostered the emergence of public mobilization and fomented a new participatory approach leading to a combative civic epistemology, recruited by activists and local populations to challenge the nuclear project and to inaugurate a new relationship between science and society.

The ongoing revolutionary period lasted until a new constitutional government was elected on April 25 ${ }^{\text {th }}$ 1976. In 20 months, there were 6 interim governments and two failed coups. Power was unstably divided and disputed among the Armed Forces Movement (MFA), the emerging political parties and reactionary actors, competing to institutionalize practices biased towards communist or liberal ideologies (Rosas 2003). Social movements emerged in a zeitgeist shaped by the new freedom to participate and to promote change, including the first environmental groups and various labor and student unions - citizens were inspired to actively participate in the restructuring of institutions, identities and social practices.

The months following April 1974 displayed a strong participative culture permeating distinct levels of the Portuguese society. This revolutionary attitude was a generalized civic duty mobilized to build a better future (Pinto 2006). The public, kept silent for almost half a century, could finally display their convictions, fighting for different causes.

The nuclear project, planned to start in the wake of the 1974 Revolution, illustrates the effects of drastic social changes on major sociotechnical programs, as the democratization process fostered a new civic epistemology that influenced the fate of the nuclear project. 


\section{Nuclear Energy After the Carnation Revolution}

If the seeds of the anti-nuclear sentiment had been sown by this nascent participatory culture, relevant institutional transformations were taking place, and JEN's bureaucratic apparatus was sanitized and democratized. General Arriaga was deposed and workers gathered to create a new Executive Commission (Oliveira 2002). João Caraça, the scientist who presided the Executive Commission, described that period as follows:

There was a burst of ideas and proposals. Because during the April $25^{\text {th }}$ Revolution, with the democratization of institutions, there was a will to try to transform the institutions for the (...) social and economic development of the country (...). This was also the case there (at LFEN). (Interview, João Caraça, May 2013)

However, in the following years JEN would be recurrently reformed until its extinction in 1979. Democratic governments maintained the orientation of the dictatorial period, transferring the State's authority to the national energy company, Electricity of Portugal (EDP) (Caraça 1978). The new democratic government first displayed an attitude of inertia towards nuclear energy, maintaining the previous style of management, for decades built upon a strong hierarchical State. Although JEN's command was being transferred to EDP and to the Ministry of Industry and Energy, the decision process depended on internal technical reports, and before the first protests there were no significant concerns about public backlash.

How can we explain this pro-nuclear imaginary after the Carnation Revolution, as the Portuguese nuclear project was a product of a Fascist ontology geared towards progress and modernity? First, and similarly to South Korea, the democratic transition did not result in an immediate change of nuclear policies, or in the questioning of ideas of development. As Jasanoff and Kim wrote, "Democratization did not immediately extend to a critical reflection of the dominant ideas of "nation" and "development" deeply embedded in the nuclear imaginary and its material products" (Jasanoff and Kim 2009: 141). In fact, the post-1974 Portuguese nuclear project was framed as a driver of development. Second, the Portuguese Communist Party, which operated clandestinely against Fascism for almost 50 years, representing the strongest ideological opposition to the "old regime," was pronuclear, as long as the reactors were Soviet. Third, there were no environmental movements in Portugal, and no organized public or local opposition to this endeavor - the anti-nuclear movement only emerged after the first demonstrations in Ferrel, in 1976. Fourth, nuclear projects can embed and be embedded by a multitude of imaginaries (containment/development, for instance) and nuclear systems themselves can elicit different technopolitical regimes. Hecht (1998) argued that the French Commissariat à l'Énergie Atomique (CEA) can be understood as a nationalistic institution while the Électricité de France (EDF) is a nationalized institution, indicating that different technological entities within the same national landscape can elicit distinct ideologies and political values (sovereignty, 
dependence, independence, etc.), reminding us that nuclear ontologies shouldn't be blackboxed.

The pro-nuclear sociotechnical imaginary fit well into the new revolutionary spirit, framed under the MFA's $3 D$ slogan: to democratize, to decolonize and to develop (Rosas 2003), understood as a fundamental step to accomplish the third $D$. However, the first $D$, to democratize, would lead to the emergence of a strong civic opposition, eventually undermining the nuclear project. The revolutionary epistemology supported the open confrontation of technical and political arguments, leading to the emergence of environmental groups, eroding the legitimacy of the nuclear energy agenda and shifting the national imaginary towards a nuclear-free future.

Public opposition to nuclear energy signals the emergence of a combative civic epistemology that was made possible by the 1974 Revolution. If the nuclear project was imagined as an exemplar of the Fascist ontology, a technoscientific device that would generate development, independence and economic prosperity, the Carnation Revolution opened the floodgates of political dissent, turning it into a driver of sociotechnical contestation and leading to the emergence of environmental activism. The advent of democracy thus paved the way for the questioning of the nuclear option, a product of the Fascist ontology that the country now rejected.

\section{Ferrel's Protests and the Emergence of an Organized Civil Opposition: The Turning Point}

The Portuguese nuclear controversy questioned sociotechnical imaginaries of development and sovereignty. The advent of a combative civic epistemology, leading to the rejection of pro-nuclear arguments, was supported by the brave actions of concerned scientists who supported the struggle of lay citizens through their expertise and technical knowledge, and the scientific community was now vulnerable to dissent and controversy.

In 1975, EDP and the Ministry of Industry and Energy promoted the first National Meeting of Energy Policy in Porto. Delgado Domingos, a nuclear scientist who advised industries in the US and was then a Professor at the Technical University of Lisbon (IST), attended the meeting. Supported by substantial knowledge about the technoscientific and economic arguments that justified the construction of the Ferrel Plant, he understood the shaky scientific and economic rationales and didn't find them convincing. He was emphatically against the project and became a well-known and respected critic of the nuclear option. He told us that he was surprised by the way most of the attendees would just accept technical arguments that could be easily contested or deconstructed (Interview, Delgado Domingos, October 2011). He actively participated in all discussions, being one of the few voices that contested the construction of the Ferrel plant. Even though he positioned himself against the nuclear endeavor at the National Meeting, the report submitted to the Minister of Industry ignored his arguments and recommended the construction of the Ferrel plant, falsely including Professor Domingos as one of the endorsers (COPENPE 1975). The Minister of Industry and Technology then 
announced the immediate beginning of construction in January 1976 (Oliveira 2002).

On March $15^{\text {th }} 1976$ about one hundred people - mainly local inhabitants of Ferrel - marched together to the construction site and forced workers to stop all construction activities, armed with farming tools, tractors and wagons (Gazeta das Caldas 2012). Although barely mediatized back then, this event was an inflection point in the Portuguese nuclear project. An anti-nuclear activist who attended the march told us that "Ferrel was the burial ground of the Portuguese nuclear project" (Interview, António Eloy, March 2013). It triggered a cascade of events and debates about the nuclear option that were crucial to define its demise. For the first time in history, there was visible opposition to the initiative. The local population feared the impacts in their backyards, and there were emerging environmentalists whose actions mirrored global anti-nuclear movements (Barca and Delicado 2016). Finally, there were scientists who contested the scientific grounds of the project.

Apart from translating information developed by European anti-nuclear movements, which allowed them to adapt arguments to the local context (Barca and Delicado 2016), Domingos and his colleagues provided the emerging civil opposition with relevant expertise that gave them more legitimacy. A well-known anti-nuclear activist, the journalist Afonso Cautela, after becoming aware of Domingos' arguments, urged him and his colleague from IST, Dr. Matos Ferreira, to get in touch with Ferrel's population and with environmental organizations, fostering a dynamic collaboration which would prove crucial in the unfolding of the controversy. Domingos' articles were increasingly discussed, and he lectured at different meetings, even with inhabitants of Ferrel who had kicked out EDP technicians from their village (Interview, Delgado Domingos, October 2011)

The environmental group Living is necessary released a series of working papers aligned with the arguments of international anti-nuclear movements (Figueiredo and Fidélis 2003). The Commission to Support the Fight Against the Nuclear Threat CALCAN, endorsed by local associations and students, sent the Ministry of Industry and Technology a telegram demanding the abandonment of Ferrel's project (Cautela et al. 1977). Simultaneously, a national manifest called We are all residents of Ferrel attained great public visibility, strengthening the movement (Pessoa 2006). In 1978, anti-nuclear activists invited Domingos, intellectuals and famous musicians to the most significant anti-nuclear protest in Portuguese history, the Festival for Life and Against Nuclear Energy. About two thousand people went to Caldas da Rainha and Ferrel to reject the nuclear option. These activists also published an influencing Black Book of Nuclear Energy (Cautela et al. 1977), assuming that it would be necessary to counter the arguments present in the pro nuclear White Book that government technicians were preparing.

From 1977 onwards, pamphlets, books, special issues of academic journals and press articles emerged from both sides of the controversy, illustrating a heated debate about technical and political aspects (Cautela et al. 1977; Torres 1977; Domingos 1978). The new free press allowed scientists, activists and politicians to display their arguments, leading to an unprecedented sociotechnical controversy. On the one hand, environmental groups produced impacting documents that depicted nuclear energy as a dangerous and risky endeavor, fueled by mushroom clouds and 
carcinogenic radiation; on the other hand, politicians, technocrats and nuclear scientists struggled to uphold the imaginary of national development and energy sovereignty fueled by the uranium reserves.

In Material Participation, Noortje Marres argues for "a non-exceptionalist understanding of the role of things in political participation: neither of humans nor of non-humans can it be assumed that they are well-equipped for politics and participation" (Marres 2012: xiii). Marres suggests that material participation "can be taken to refer to a distinctive mode of engagement, one in which everyday material actions, like washing or foresting, are put forward as useful and valuable operations upon matters of public concern" (Marres 2012: x).

Marres' insights are particularly well aligned with the Portuguese anti-nuclear phenomenon. First, the Ferrel uprising, resulting in the suspension of construction activities, inaugurated a new civic epistemology in Portugal, characterized by a combative style, and it was a particular technoscientific project - and the risky materiality of a future nuclear plant - that fostered new science/society couplings. Second, everyday material actions, such as farming and fishing, were considered as being under threat by the nuclear endeavor. According to Silvino João, a local resident we interviewed, when the local population realized that the Nuclear Plant would lead to a rise in water temperature, they became aware they would no longer be able to capture sardines, causing an upheaval during one of the information sessions with members of JEN. During the Festival for Life and Against Nuclear Energy, farming was explicitly mobilized as a form of anti-nuclear activism, as José Silva, a journalist and activist, told us:

We organized a symbolic plantation of potatoes. Because this was a community area, used by Ferrel's farmers to plant potatoes. (Interview, José Silva, April 2013)

Third, the first Ferrel march was marked by the use of farming tools, which both served as weapons to intimidate construction workers and also as symbols of activities jeopardized by the nuclear endeavor. Moreover, the assembly of Ferrel's population took place after everyone heard the church bell ringing. Bells are material devices that often mediate affective and social change (Carvalho 2014) - in the case of Ferrel they were used to assemble the entire population. Silvino João told us that:

In order to go to the construction site we needed to create a certain impact in the village. And we thought... there was something that was frequently done back then, which was ringing the bell. (Interview, Silvino João, April 2013)

The first protest actions and the subsequent anti-nuclear movement also led to the emergence of various cultural artefacts such as stickers, newspapers and even protest songs (Barca and Delicado 2016).

We should also explain how local, national and international debates influenced each other. During the first march there were no explicit links with national or international groups - the local population was supported by the local Fishermen's Union and the badly organized post-revolutionary Municipal Council. Both the Socialist and the Communist Party favored the nuclear endeavor. As the movement attained a national dimension, journalists, activists and concerned scientists flocked 
to Ferrel to support the population. The post-revolutionary impetus favored not only political but also epistemological symmetry. During the 1970s literacy campaigns were systematically promoted by the MFA, building on the toolkit developed by Freire, the Brazilian educator who argued that knowledge and social transformation are profoundly intertwined (Freire 1970). According to Matos Ferreira,

It wasn't only the MFA that organized literacy campaigns, we did that as well, (...) scientists and (...) qualified people, we talked about relevant and important themes. (Interview, Matos Ferreira, April 2013)

This engaged and participatory civic epistemology was supported by international debates and methodologies pertaining to the European anti-nuclear movements of the 1970s. The majority of anti-nuclear activists we interviewed had spent some time in France studying. There, they were exposed to one of the most dynamic environmental movements in Europe. According to José Marques, from the environmental group Living is necessary, this intersection between national and international debates played a fundamental role:

I think there was a strong connection between the groups and people that assembled or shared an anti-nuclear stance, internally, but also externally, because they were aligned with (...) the anti-nuclear movement in the US, France and Germany... it was a strong and broad set of arguments that was very much present and that expressed itself in publications of these small groups, perhaps in more lyrical ways (...). In other cases it expressed itself in more technical ways. (Interview, José Marques, June 2011)

Sometimes these national/international entanglements led to the translation of documents into Portuguese, as António Correia, a local inhabitant, told us:

I adapted...we made those stickers, connected to the sun (...) And then, the nuclear power plant that said something like je ne fume pas, mais je tue. So, I don't smoke but I kill. I translated that into Portuguese. (Interview, António Correia, April 2013)

The alignment of Portuguese and international activists was reinforced in 1978, during the Festival for Life and Against Nuclear Energy, attended by members of European anti-nuclear groups. António Eloy became one of the most prominent anti-nuclear voices in Portugal, and started participating in international meetings in Europe and the US. His cooperation with Spanish activists led to the creation of the Iberian Antinuclear Movement in 2015, recognizing that Spanish power plants can have disastrous consequences in Portugal (Eloy 2017).

The nuclear controversy was a platform for dispute, and the first democratic governments realized that it triggered strong social opposition - fearing the electoral influence of a premature decision, the first constitutional governments opted to postpone any action until consensus could be reached. The official announcement, by the Secretary of State for the Environment, in 1986, took ten years to be released, and it was finally stated that nuclear energy was no longer an option (Santos Pereira et al. 2016). 
Ferrel was the first sociotechnical controversy in Portugal's contemporary history (Delicado 2013) and it constitutes an emblematic case study to analyze how processes of democratization transform sociotechnical policies. Portuguese civic epistemologies only really emerged after 1974, when citizens attained the freedom of assembly and the press was no longer censored. These new political rights triggered severe social changes, and Ferrel worked as a catalyst to question nuclear development. The first demonstrations, led by local inhabitants, quickly escalated and gained national and international visibility, and the nuclear issue paved the way for a social movement that proliferated due to the new freedoms granted by the Revolution.

These events indicate a transition towards a co-productionist and participatory way of governing and developing nuclear technologies, where all relevant stakeholders - scientists, technicians, local inhabitants, activists, and lay citizens - take part in a wider social debate on technological futures, suggesting that sociotechnical imaginaries are no longer controlled by an elite but can be actively contested by the majority of the population.

The local population, supported by environmental groups, scientists, artists and lay citizens, gained a voice in the ongoing sociotechnical discussions, indicating the emergence of a new relationship between government and populace. The Carnation Revolution did not result in a magical transformation of Portuguese science/society couplings, but provided room for the contestation of official, State-led sociotechnical imaginaries, and technoscientific entities progressively became matters of concern.

\section{Portuguese Imaginaries in Clash}

The nuclear controversy was characterized by a wide range of pro and anti-nuclear arguments. Although government officials tried to salvage the sociotechnical imaginary of development and economic prosperity, the newly attained political freedoms resulted in forms of epistemological contestation that turned the nuclear endeavor into a vibrant controversy.

From the pro-nuclear perspective, nuclear energy provided an autonomous source of electricity, and nuclear development would be the first high-tech industry of Portugal (Moura et al. 1978). For decades, the government funded scientists to study abroad and by the end of the 1970s there were significant human resources that should not be wasted. This scientific elite favored the development of a national nuclear industry and policymakers wanted to finally profit from their investment (Cautela et al. 1977). Pro-nuclear advocates argued that Spanish nuclear plants were already a risk, therefore Portugal should not be afraid of plants within its borders. Once the necessity to diversify energy sources became consensual, an elite of scientists struggled to maintain the previous governmental orientation that recognized nuclear fuel, based on national uranium, as a better option than importing fossil fuels (Delicado 2013). Although renewable energy sources were emerging as potential alternatives, they were not an affordable option (Silva et al. 1977).

However, nuclear enthusiasts were not prepared to consistently rebut every antinuclear argument. The former head of JEN's executive commission reported that they regretted the way they dealt with the public: 
It is the same case of putting face to face an astronomer and an astrologist. The first will always lose, since he works with doubts, and the second one with certainties. (Interview, João Caraça, May 2013)

The opposing voices relied on sound technical arguments. First, the chosen location was contested, due to the impacts on the environment, the local economy and the lack of data on seismic hazards. In 1981 it was found that Ferrel was located near a seismic fault, undermining the construction of a nuclear plant (Santos Pereira et al. 2016). Second, economic arguments were also questioned. Although the country had significant uranium reserves, it lacked the technology to benefit from them - it would be necessary to import, or at least exchange, nuclear fuel with foreign countries (Silva et al. 1977). Also, EDP's approach, which in order to commission the power plant in a short period of time assumed the need to import all core technologies, was not attractive to national industry, generating complaints from JEN's nuclear scientists (Jorge and Costa 2001). Meanwhile, there were strong objections against the elaborated economic scenarios of growth and energy demand. Nuclear energy was recurrently characterized as an expensive extravagance (Amigos da Terra 1987) and many argued that, if the US, by the end of 1970s, was slowing down its nuclear industry development, there should be relevant reasons to question the pertinence of a nuclear plant in Portugal.

Although there were also emotional and ideological arguments against nuclear energy, there was a consistent technical argumentation that portrayed the nuclear option as economically irrational. The anti-nuclear movement was able to give visibility to debates and to mobilize media and politicians, preventing various democratic governments to assume pro-nuclear decisions. From 1976 onwards (after the Three Mile Island incident), TV programs mirrored local and international reactions against the nuclear option (Schmidt 2003) and, in the early 1980s, an inquiry showed that $70 \%$ of respondents were against it (Fernandes 1986).

According to Jasanoff and Kim (2009: 125), "the term "anti-nuclear" encompasses social movements against weapons as well as power plants." The rise of a pervasive anti-nuclear sentiment in Portugal indicates that social movements were successful in questioning the imaginaries of containment and development. Anti-nuclear imaginaries highlighted the risky, uncontainable dimensions of nuclear energy and also its economic irrationality. By highlighting that core technologies would have to be imported, along with enriched uranium, development, independence and sovereignty were in fact threatened by the nuclear endeavor. In contrast with South Korea, the Portuguese anti-nuclear movement managed to shatter the sociotechnical imaginary focused on atoms for development (Jasanoff and Kim 2009).

\section{The Government's Reaction: Education, Dialogue and Persuasion}

Given the new political environment, characterized by epistemological contestation, the sociotechnical imaginary of development and modernization could only be rescued if the public felt part of decision-making processes. Top-down decisions 
needed to be legitimized by information sessions and dialogue, turning the nuclear endeavor into a co-produced project.

The government and EDP recognized the need to address public concerns. Instead of following traditional ways of decision-making, characterized by centralization and lack of transparency, the government attempted to deal with a myriad of technical and political arguments stemming from official experts, social groups and academia. The attractiveness of nuclear power plants was now on trial, and the government had to deal with a collective that refused a passive role, resulting in a highly disputed controversy.

The strategy was grounded on two modes of reasoning. The first one has to do with the deficit model of public understanding of science (Jasanoff 2005), which justifies public resistance to technologies according to the lack of scientific knowledge. JEN created the General Directorate for Public Communication (Oliveira 2002) and EDP released pamphlets about the safety of the power plant to be distributed among Ferrel's population. This educational perspective never succeeded, as the controversy was already established.

The second approach concerned an apparent willingness to dialogue with the opposing groups, hoping to convince them of the benefits of nuclear energy. Jaime Oliveira, a pro-nuclear scientist who actively participated in those meetings, told us that JEN workers truly believed in the value of the nuclear project, and it was their duty to provide the adequate information to convince the public (Interview, Jaime Oliveira, January 2013). The Minister of Industry and Technology participated in a roundtable with scientists and environmentalists and in a TV program in 1979, and published articles in academic journals (Silva et al. 1977). The Democratic Revolution altered the attitudes of official experts, aiming at engaging in an open debate with all stakeholders.

Another example took place in 1977, during the second National Meeting of Energy Policy, organized by EDP. There was an unprecedented openness to divergent voices, contrasting with the previous meeting. There were more than 600 attendees - 50 of them belonged to civic organizations, including environmental and local action groups - and there were sessions on controversial issues, such as the economic viability of nuclear energy and the environmental impacts and safety of the Ferrel plant (COPENPE 1977).

The government responded by calling for a commission of experts from JEN, in 1976, to prepare a White Book of Nuclear Energy, ideally paving the way for parliamentary debates and deliberation. The book was completed in 1978 and presented a favorable view of nuclear energy, although not recommending any immediate decision (Sousa et al. 1978). However, it was not immediately published and the Parliament never had access to it, triggering heated debates and leading some MPs to question the government's transparency and efficiency.

Meanwhile, some scientists published the Grey Book of Nuclear Energy, which should provide reasonable arguments in order to support a consistent debate on the issue (Moura et al. 1978). There was also a petition, signed by more than 100 Portuguese scientists, demanding an open dialogue on the topic. Academia was mobilized and even nuclear scientists who supported the project believed a debate was necessary. Another crucial aspect was the delegation of authority and 
responsibility from the State to EDP. According to some nuclear physicists we interviewed, EDP did not have sufficient technical and management capacity to carry out such a complex project, and they were concerned with the delegation of power to a commercial corporation, feeling this would prevent their open participation in the unfolding of the controversy.

This approach indicates that there were conflicting imaginaries between the public and government officials. In order to promote a pro-nuclear sociotechnical imaginary, initiatives of top-down communication and public deliberation were put in place to educate the public. If the population demanded a more participatory decision-making process, there were also academics who supported the public in countering the technical arguments put forward by experts and government officials. Professor Domingos played a fundamental role during this process, and according to Silvino João he used his technical and scientific expertise to counter pro-nuclear arguments:

There was an event when some members of JEN came here, for an information session, but we had Professor Domingos in the audience. When they realized he was there their discourse immediately changed. He started questioning them, and defended us with tooth and nail. (Interview, Silvino João, April 2013)

Professor Domingos acted as a concerned scientist, supporting the public in the enactment of an anti-nuclear imaginary and challenging the narratives of containment and development, allowing the population to rebut the technical grounds underlying the nuclear option.

\section{The Settling Down of the Controversy}

The vibrant anti-nuclear movement included local residents, activists and scientists who contested the technical and ideological rationale of the endeavor. Their growing pressure demanded more information on the technical grounds supporting the project, which eventually showed that Ferrel was not a suitable location.

The Nuclear Protection and Safety Cabinet (NPSC), operating within the Ministry of Energy and Industry, replaced JEN's General Direction of Fuel and Nuclear Reactors and was responsible for regulating nuclear plants. Under significant pressure by the public, it collected and analyzed all EDP's technical data on Ferrel's nuclear project and, aligned with IAEA's suggestions, requested more data on local seismic activity (Oliveira 2002), which showed the existence of a seismic fault. This led EDP to announce in 1981 the end of the nuclear project in Ferrel, suggesting that further studies should be carried out (Santos Pereira et al. 2016). It was a decisive blow on Portuguese nuclear ambitions, meaning that all studies would have to return to the prospective stage, as EDP stated that it was now necessary to undergo studies in order to find a new location (Oliveira 2002).

After Ferrel was considered an inadequate location and taking into account the economic costs and the grim scenario of a potential accident, the government put a damper on the nuclear project. It progressively lost media attention, and the government stopped fomenting a public debate on the matter. Despite these 
setbacks, nuclear energy was still a relevant option that had to be temporarily delayed, as the pro-nuclear lobby kept exerting its influence. The strategy called again for a technocratic governance through the National Energy Plan (PEN) (Portugal - Direção Geral de Energia 1982). This 1,000-page document presented a thorough analysis of the country's energy situation and consisted of 3 different reports: the main report with all the relevant data and technical attachments; a synthesis report comprising 140 pages, aimed at supporting decision-making; a summary and conclusions of approximately 45 pages.

Nuclear energy was included in all future energy scenarios alongside other energy sources, but in the main report there was a section exclusively focused on nuclear energy, entitled Program for the Introduction of Nuclear Energy (pp. 303 336). Both medium and long term energy plans contemplated the implementation of nuclear energy, as well as the conservation of energy, the use of coal, natural gas and renewable energy sources (biomass and hydropower). The PEN projected the beginning of nuclear energy production in 1995 with a nuclear plant of $950 \mathrm{MWe}$, and in a scenario of smaller economic growth, from 4000 to $6000 \mathrm{MWe}$ of installed nuclear power until 2010.

The PEN generated opposition from environmental groups, triggering debates about the national energy policy (Schmidt 2003), highlighting the biased character of the studies and criticizing the composition of the Executive Commission (Amigos da Terra 1987: 88). Once again, strong public opposition compelled the government to review its original strategy, leading to a new PEN, published in 1984 (Portugal Direção Geral de Energia 1984). It contemplated the installation of nuclear power plants but with fewer ambitions. By the end of 1984, EDP identified potential sites for the construction of two 1000 MWe groups, and in 1985 it revised these findings, according to a set of recommendations from IAEA experts. However, the results were never presented to the public (Oliveira 2002). The issue faded away again while the government maintained its irresolution. The second PEN was never submitted to the Parliament, indicating a lack of political cohesion on the topic.

In 1986, after the overwhelming impacts of Chernobyl, commissioning nuclear power plants was excluded from energy policy discourses. The emphasis shifted to natural gas, coal, and the diversification of energy resources. In 1986 the Secretary of State for the Environment publicly declared that Portugal abandoned the nuclear option, a decision later ratified by the following Prime Minister in 1987 (Santos Pereira et al. 2016).

Democracy led to the emergence of a civic epistemology that legitimized popular perceptions of technology, and policymakers could not blindly accept official reports. Decisions on nuclear energy were now affected by a new social context marked by contestation, freedom and the questioning of elites and experts, leading an anti-nuclear group in Portugal to state that "Democracy is the natural enemy of the nuclear option" (Amigos da Terra 1987: 12). 


\section{Revolutionary and Post-Revolutionary Civic Epistemologies: Impacts on Nuclear Imaginaries}

The anti-nuclear movement was characterized by a combative civic epistemology never before witnessed in Portugal, challenging the sociotechnical imaginary which conceived nuclear plants as a solution to the country's energy autonomy and a factor of development. This combative civic epistemology, which allowed various kinds of knowledge claims to resonate in public arenas, required an accountable examination of the technical, political and ideological foundations of the nuclear program and an awareness of its alternatives.

In a previous paper we analyzed the historical evolution of the political discourse on nuclear energy in Portugal (Santos Pereira et al. 2016), arguing that, if initially it was framed as a technical issue, it progressively became a sociotechnical one. This was illustrated by the emergence of frames dealing with the environment, health, and the population, rescuing nuclear energy from its Fascist technocratic blackbox. As we argued, nuclear accidents, joining the European Union in 1986 and the alteration of energy policies played an important role during this process.

The unfolding of these different arguments and phenomena should also allow us to question the role of Ferrel and of social movements in general in the demise of the nuclear endeavor. When we asked Delgado Domingos about the role of antinuclear demonstrations he was a bit skeptical:

(...) we shouldn't be lyrical about that. I think that what mattered was the money. Popular demonstrations were important, no doubt about that, but I think they weren't decisive. (Interview, Delgado Domingos, October 2011)

During the Fascist regime the main argument supporting the nuclear endeavor was to profit from continental and colonial uranium reserves, and there were also strategic ambitions. After the Carnation Revolution, there was an attempt to find alternatives to foreign oil, motivated by the oil crisis of the 1970s. Although the post-revolutionary political discourse still presented nuclear energy as a driver of development and sovereignty, the changes in JEN's structure meant that the nuclear option progressively became less of a strategic or national mission, it became just another business. According to João Caraça,

The political elites were completely changed. Therefore, industrial and commercial interests became stronger. (Interview, João Caraça, May 2013)

According to most of our interviewees, nuclear energy was not implemented for economic reasons, and not due to strong anti-nuclear opposition. There are five main reasons that can explain the decision to opt out of the nuclear endeavor: 1) Due to the end of the colonial rule, Portugal could no longer use the uranium from its former colonies; 2) Portugal didn't have the necessary technologies and expertise to build a nuclear plant from scratch, and national industry wouldn't benefit from turnkey projects - moreover, the grim economic context (Portugal required assistance from the International Monetary Fund in 1977 and 1983) didn't favor a direct and massive intervention by the State; 3) a strong anti-nuclear sentiment 
started developing in some factions of the Social Democracy Party, and the Communist Party, realizing that enriched uranium would have to be imported from the United States, was now against this imperialist endeavor; 4) there were strong environmental concerns that progressively attained visibility, motivated by the Three Mile Island Accident (1979) and Chernobyl (1986), undermining the discourse of containment; 5) less controversial energy sources became more viable, such as natural gas and coal. Although social movements galvanized the public and had some political resonance, the demise of the nuclear option needs to be assessed in light of a wider socioeconomic and geopolitical context.

Although it wouldn't be correct to postulate a direct correlation between the antinuclear movement and the demise of the nuclear option, this controversy illustrated the emergence of a combative and pluralist civic epistemology. A set of values that emerged during the revolutionary period led to new ways of legitimizing technical knowledge. There should be no room for autocratic decisions in any branch of the government, and there was an emphasis on accountability and the defense of public interest. This was supported by new mechanisms of counter-expertise, demands for access to information and social mobilization. The authority of the State was contested, and this emerging way of public reasoning promoted a critical examination of technical statements.

The Portuguese democracy faced itself in the conjunction of a nuclear heritage from the dictatorship and the emergence of a vibrant anti-nuclear movement (Barca and Delicado 2016). The civic opposition mobilized by social actors such as CALCAN, Domingos, Cautela and the myriad of recently freed political activists who saw the nuclear ban as a honorable cause aimed at influencing the public against the nuclear option. This illustrated an epistemic reshaping, a progressive openness towards technical dissidence, favoring a combative civic epistemology.

This scenario forced every following constitutional government to postpone decisions that could have negative impacts on electoral outcomes. While governments kept a consensual delaying, the confrontation of the official expert reasoning led to an introduction of other nuclear imaginaries, where images of fear, destruction, and economic costs jeopardized the previous vision of nuclear energy as a driver of modernity.

During the ripple of the revolution, social protests influenced politicians to postpone their decision, but the effective abandonment of the nuclear option was consolidated by the organized rebuttal from opposing experts that followed every attempt to technically justify the nuclear project. However, although a pluralist - or combative - style of public knowledge making emerged after the revolution, it was gradually diffused over the following years, leading to the stabilization of democratic institutions and their knowledge claims, and to a more technocratic and less participative culture. 


\section{Conclusion}

The Portuguese nuclear endeavor could initially be understood as reflecting a Fascist ontology, being rehabilitated by the early post-revolutionary governments until the first anti-nuclear mobilizations took place. The anti-nuclear protests illustrated the emergence of a new civic epistemology, challenging the sociotechnical imaginaries of development.

As Winner suggested, technological artifacts can have "political qualities" (Winner 1980: 38) which have to do with the technical objects themselves, and not exclusively with the contexts in which they are situated (ibid: 39). Winner contrasted the politics of solar and nuclear energy, arguing that we can look at solar energy as "decentralizing in both a technical and political sense" (ibid: 34), whereas nuclear energy relies on a "techno-scientific-industrial-military elite" (ibid: 32).

One could argue that nuclear energy was in line with the Fascist ontology of the dictatorial State; however, the imaginary of development was also fostered by the early democratic governments, meaning that we should question deterministic approaches to technology. Different ontologies (Fascist and Democratic) and sociotechnical imaginaries can be entangled with nuclear projects.

Although it would be romantic (or lyrical, as put by an interviewee) to interpret the demise of the nuclear option as a direct result of anti-nuclear social movements, this sociotechnical controversy is an interesting case to study the articulations of sociotechnical landscapes and major social and political changes, leading to the emergence of particular civic epistemologies

The openness to public participation, counter-expertise and massive demonstrations allowed the opponents of the nuclear project to associate the public imagination of nuclear technology with risks and negative impacts. The birth of Portuguese civic epistemologies directly questioned official and governmental sociotechnical imaginaries, and the participatory and revolutionary spirit that permeated Portuguese society in the years following the Carnation Revolution worked as a sociocultural catalyst for public dissent.

As we have suggested elsewhere (Santos Pereira et al. 2016), Portuguese civic epistemologies are technology specific. The public was utterly ignored during the unfolding of other socio-technical controversies in Portugal during the 1990s and 2000s such as genetically modified organisms (GMOs) and bovine spongiform encephalopathy (BSE), and the potential risks of emerging technologies haven't generated much public participation (Carvalho and Nunes 2013, 2018). The permeability of nuclear energy policy to social mobilization clearly contrasts with other technologies, turning it into an emblematic case study to analyze how major technological projects and State-sanctioned sociotechnical imaginaries can be questioned by a multitude of social actors.

The history of nuclear energy in Portugal is an interesting example to analyze how processes of democratization affect science/society couplings and how technoscientific options can encompass multiple imaginaries. However, it should also remind social scientists and historians of the limits of narrative. As we have seen, the demise of the nuclear option and the closure of this iconic controversy can 
only be partially explained by the anti-nuclear movement. This indicates that democratic transitions are not necessarily accompanied by major sociotechnical shifts and that social dissent and engagement with science and technology, despite being crucial to understanding the public perception of certain sociotechnical options, need to be put in context, as economic, institutional and political factors played a determinant role in the Portuguese case.

\section{References}

Abraham, Itty. 2006. The Ambivalence of Nuclear Histories. Osiris 21(1): 49-65.

Amigos da Terra. 1987. Antes, Durante e Depois de Chernobyl - O Nuclear no Mundo e em Portugal. Lisboa: Associação Portuguesa de Ecologistas.

Barca, Stefania, and Ana Delicado. 2016. Anti-Nuclear Mobilisation and Environmentalism in Europe: A View from Portugal (1976-1986). Environment and History 22(4): 497-520.

Cabral, Joaquim, and Abílio Fernandes. 1975. Central Nuclear de Ferrel - estudo preliminar e de localização. Lisboa: CPE/EDP.

Caraça, João. 1978. Como a energia nuclear foi introduzida e fomentada em Portugal. In $O$ que é a energia nuclear: oportunidade em Portugal, eds. Domingos Moura, et al., 129-142. Lisboa: Moraes Editores.

Carvalho, António. 2014. Subjectivity. Ecology and Meditation: Performing Interconnectedness. Subjectivity 7(2): 131-150.

Carvalho, António, and João Arriscado Nunes. 2013. Technology, Methodology and Intervention: Performing Nanoethics in Portugal. Nanoethics 7(2): 149-160.

Carvalho, António, and João Arriscado Nunes. 2018. Assembling Upstream Engagement: The Case of the Portuguese Deliberative Forum on Nanotechnologies. Nanoethics. https://doi.org/10.1007/s11569018-0314-0.

Castaño, David. 2011. O Aliado Fiel. As negociações para o acordo de exploração e exportação de urânio de 1949. Ler História 60: 133-150.

Cautela, António, et al. 1977. O suicídio nuclear Português. Lisboa: Socicultur.

COPENPE. 1975. Encontro Nacional Sobre Política Energética - Relatos-Sintese dos Debates, Recomendações e Conclusões. Porto: COPENPE.

COPENPE. 1977. Encontro-Debate sobre a Instalação das Centrais Nucleares em Portugal - Resumo das Sessões de Debate. Lisboa: COPENPE.

Delicado, Ana. 2013. Scientists, Environmentalists and the Nuclear Debate: Individual activism and collective action. In Associations and Other Groups in Science: An Historical and Contemporary Perspective, ed. Ana Delicado, 189-208. Newcastle: Cambridge Scholars Publishing.

Domingos, José. 1978. Inteligência ou Subserviência nacional? O Absurdo duma opção Nuclear. Porto: Afrontamento.

Eloy, António. 2017. Almaraz e outras coisas más. Caldas da Rainha: Gazeta das Caldas.

Fernandes, José. 1986. Política Energética na Imprensa Portuguesa - Esboço de um Debate Público. In Conferência sobre Política Energética em Debate, ed. Sidónio Branco, 17-24. Lisboa: Centro de Estudos em Economia em Energia dos Transportes.

Ferreira, José. 2004. A Importância do Ultramar para a Economia Nacional. Revista Militar 2424: 1-28. Freire, Paulo. 1970. Pedagogy of the Oppressed. New York: Continuum.

Galvão, Júlio. 2013. A Pré-História do Reactor Português de Investigação. Gazeta de Física 36(2): 4-7.

Gaspar, Júlia. 2011. O Reactor Português de Investigação na encruzilhada com o desenvolvimento da física moderna em Portugal e os átomos para a paz (1952-1961). Gazeta de Física 34(2): 58-62.

Gazeta das Caldas. 2012. Os 36 anos do levantamento de Ferrel contra o Nuclear foram assinalados em Peniche http://gazetacaldas.com/sociedade/os-36-anos-do-levantamento-de-ferrel-contra-o-nuclearforam-assinalados-em-peniche/. Accessed 8 September 2016.

Hamann, K., and P.C. Manuel. 1999. Regime Changes and Civil Society in Twentieth-Century Portugal. South European Society and Politics 4(1): 71-96.

Hecht, Gabrielle. 1998. The Radiance of France: Nuclear Power and National Identity After World War II. Cambridge, MA: The MIT Press. 
Hecht, Gabrielle. 2006. Nuclear Ontologies. Constellations 13(3): 320-331.

Hecht, Gabrielle (ed.). 2011. Entangled Geographies: Empire and Technopolitics in the Global Cold War. Cambridge, MA: MIT Press.

Jasanoff, Sheila. 2004. The Idiom of co-production. In States of Knowledge: The Co-Production of Science and Social Order, ed. Sheila Jasanoff, 1-12. London: Routledge.

Jasanoff, Sheila. 2005. Designs on Nature: Science and Democracy in Europe and The United States. New Jersey: Princeton Universtiy Press.

Jasanoff, Sheila. 2015. Future Imperfect: Science, Technology, and the Imaginations of Modernity. In Dreamscapes of Modernity: Sociotechnical Imaginaries and the Fabrication of Power, eds. Sheila Jasanoff, and Sang-Hyun Kim, 1-33. Chicago and London: The University of Chicago Press.

Jasanoff, Sheila, and Sang-Hyun Kim. 2009. Containing the Atom: Sociotechnical Imaginaries and Nuclear Power in the United States and South Korea. Minerva 47(2): 119-146.

Jorge, Henrique, and Carlos Costa. 2001. O Reactor Português de Investigação no panorama científico e tecnológico nacional 1959-1999. Lisboa: Ministério da Ciência e Tecnologia; Sociedade Portuguesa de Física.

Marres, Noortje. 2012. Material Participation - Technology, the Environment and Everyday Publics. London: Palgrave Macmillan.

Miller, Clark A. 2008. Civic Epistemologies: Constituting Knowledge and Order in Political Communities. Sociology Compass 2(6): 1896-1919.

Mol, A. 1999. Ontological politics: A word and some questions. In Actor Network Theory and After, eds. J. Law, and J. Hassard, 74-90. Oxford: Blackwell.

Moura, Domingos, et al. 1978. O que é a energia nuclear: oportunidade em Portugal. Lisboa: Moraes Editores.

Oliveira, Jaime da Costa. 2002. A Energia Nuclear em Portugal - Uma Esquina da História. Santarém: O Mirante.

Oliveira, Jaime da Costa. 2005. O reactor nuclear português: fonte de conhecimento. Santarém: O Mirante.

Oliveira, Jaime da Costa. 2013. Meio século de estudos de reactores nucleares em Portugal. Que estratégias? Gazeta de Física 36(2): 14-21.

Pessoa, Carlos. 2006. O sino da aldeia dobrou contra a central nuclear há 30 anos, in Público. https:// www.publico.pt/sociedade/jornal/o-sino-da-aldeia-dobrou-contra-a-central-nuclear-ha-30-anos67935. Accessed 7 September 2016.

Pinto, António. 2006. Authoritarian Legacies, Transitional Justice and State Crisis in Portugal's Democratization. Democratization 13(2): 173-204.

Portugal - Direção Geral de Energia. 1982. Plano Energético Nacional na Produção de Electricidade: Versão 1982. Lisboa: Minstério do Equipamento Social and Conselho Superior de Obras Públicas e Transportes.

Portugal - Direção-Geral de Energia. 1984. Plano Energético Nacional: Relatório de Base. Lisboa: Ministério da Indústria e Tecnologia.

Ribeiro, José, et al. 1987. Grande indústria, banca e grupos financeiros - 1953-73. Análise Social 23(99): 945-1018.

Rosas, Fernando. 2003. Pensamento e Acção Politica - Portugal Século XX (1890-1976). Lisboa: Lusomundo.

Rollo, Maria, et al. 2012. Da Junta de Educação Nacional ao Instituto Camões. Lisboa: Imprensa Nacional Casa da Moeda.

Saraiva, Tiago. 2016. Fascist Pigs. Cambridge, MA: MIT Press.

Saraiva, Tiago, et al. 2008. Configurações da Investigação Científica em Portugal: 3 Estudos de Caso. In Itinerários. A investigação nos 25 anos do ICS, eds. S. Aboim, et al., 429-450. Lisboa: Imprensa de Ciências Sociais.

Salazar, António de Oliveira. 1954. Posse dos membros da JEN. In O Reactor Nuclear Português, ed. J. Oliveira (2005), 431-432. Santarém: O mirante.

Santos Pereira, Tiago, António Carvalho, and Paulo Fonseca. 2016. Imaginaries of Nuclear Energy in the Portuguese Parliament: Between Promise, Risk, and Democracy. Public Understanding of Science 26(3): 289-306.

Schmidt, Luísa. 2003. Ambiente no Ecrã - emissões e demissões no serviço público televisivo. Lisboa: Imprensa de Ciências Sociais.

Schmitter, Philippe. 1999. Portugal: do autoritarismo à democracia. Lisboa: imprensa de Ciências Sociais. 
Silva, Helena, et al. 1977. Mesa Redonda - O núcleo do nuclear ou energia nuclear, uma ilusão cara? Raiz e Utopia 1: 94-130.

Sousa, Alfredo, et al. 1978. Centrais Nucleares Em Portugal - Projecto de Livro Branco. Lisboa: Ministério da Indústria e Tecnologia.

Torres, Isabel. 1977. Centrais Nucleares e Meio Ambiente. Lisboa: Arcádia.

Winner, Langdon. 1980. Do Artifacts Have Politics? Daedalus 109: 121-136. 